\title{
IMPACTS OF FOREIGN DIRECT INVESTMENT ON POVERTY ERADICATION IN ASEAN-5 COUNTRIES
}

\author{
Shania Puteri Azaria ${ }^{1}$, Estro Dariatno Sihaloho ${ }^{2}$ \\ ${ }^{1}$ shania.azaria@gmail.com \\ Universitas Padjadjaran \\ J1. Raya Bandung Sumedang KM.21, Jatinangor, Kabupaten Sumedang, Jawa Barat 45363
}

received: 3/6/21; revised: 9/9/21; approved: 20/12/21

\begin{abstract}
This research aims to investigate the relationship between foreign direct investment (FDI) and poverty using panel data of five ASEAN upper and lower middle-income countries for 28 years. The time series data period selected in this study is from 1990 until 2018. The five countries selected to be investigated in this research are presumed as the Tiger Cub Economies, namely Indonesia, Malaysia, Thailand, Vietnam, and the Philippines. This study conducted the Feasible Generalized least Square (FGLS) methods to analyze the statistical panel data. The result from this analysis indicates that foreign direct investment has a negative and significant impact on poverty in five ASEAN countries. Other important results from this study showed that the Gross Domestic Product $(G D P)$, credit provided by the financial sector as the proxy of financial development, and education variables contribute significantly to lower poverty incidence. Policies that focus on attracting foreign direct investment, improving financial development, and support a higher level of education have the potential to reduce poverty in the selected five ASEAN countries.
\end{abstract}

Keywords: ASEAN; time series data; feasible generalized least square; foreign direct investment; poverty

\section{INTRODUCTION}

Over the past few decades, the world has become more integrated and started to open up itself to increase trade and capital flows with the rest of the world. When the world is more integrated, it will create more investment opportunities (Hanusch et al., 2018). Investments that occur in a country consist of government investment and private investment. Government investment can be carried out through government expenditure for investment, while investment from the private sector can come from domestic or foreign countries. Investment coming from abroad can be obtained in the form of foreign direct investment (FDI) and portfolio equity investment (Nizar et al., 2013). By definition, FDI is an equity investment from abroad issued by private multinational corporations (Smith \& Todaro, 2015). Essentially, FDI is an investment that requires a minimum of ten percent from company ownership (Hung, 2005). In addition, foreign direct investments can be in the form of greenfield investment, where the investor establish a new enterprise in a foreign country by building new operational facilities; joint venture, where the investor create a partnership agreement with a company overseas to build a new company; or acquisition and merger, where the investor acquires an existing company from overseas (Prince \& Fantom, 2014).

Many evidence shows that foreign direct investment is the main component of successful economic growth and development (Klein et al., 2001; Iamsiraroj, 2016; Jugurnath et al., 2016). A higher growth rate within a country will potentially encourage a rapid decrease in poverty (Agrawal, 2007). Apart from encouraging growth, FDI has other preferable features that affect the quality of growth and contribute to poverty which are, FDI helps the poor to cut down the unfavourable effect proceeded from financial instability, helps to upgrade corporate governance, help to promote environmental and labor standards, creates jobs, develops local skills, encourage technological progress, enhances the productivity of host countries, and provides taxes that promote the development of a safety net for the poor (Klein et al., 2001; Hung, 2005; Ahmad et al., 2019; Lee, 2013)

The global inflow of foreign direct investment (FDI) fell to 23 percent in 2017 from the preceding year on account of $\$ 1.43$ trillion from $\$ 1.87$ trillion in 2016 (Figure 1). Additionally, inflow of FDI fell rapidly in developed economies and economies in transition while those developing economies remained stable. Consequently, in developing economies, the FDI inflow showed an increasing share and gained 47 percent in 2017 as opposed to 36 percent in 2016 (UNCTAD, 2018). 


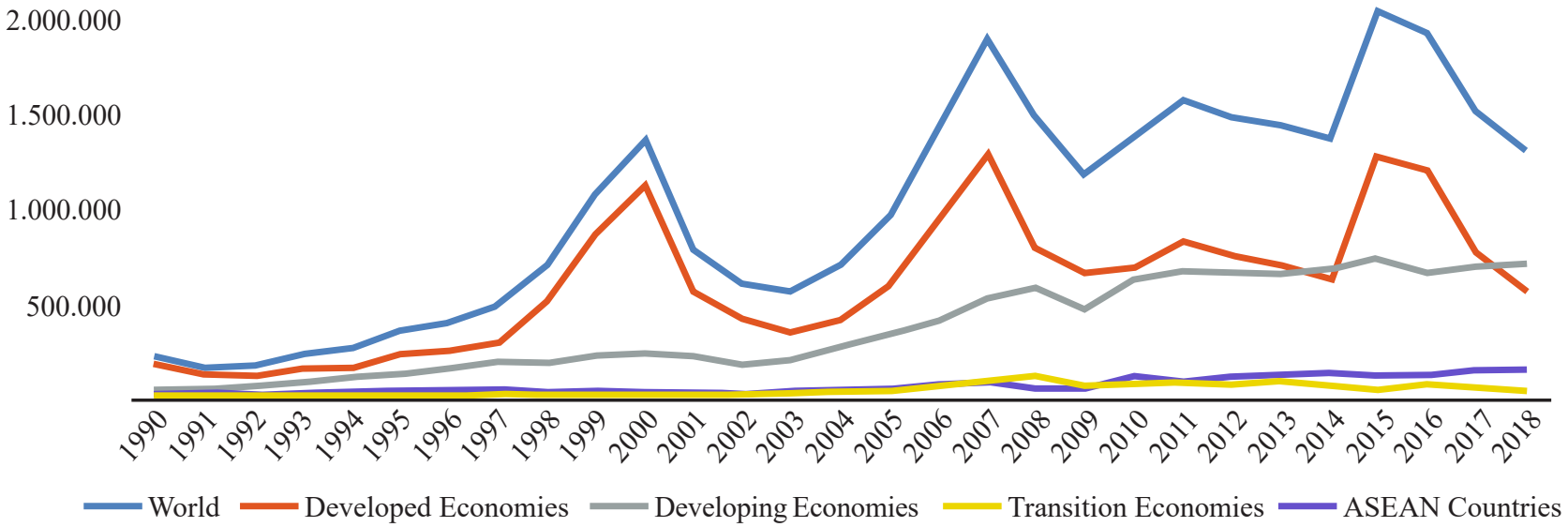

Source: Constructed using data from unctad.org

Figure 1. FDI inflows, global and by group of economies, 1990-2018

Meanwhile, since the formation of ASEAN in 1967, this organization has integrated its markets to ASEAN member economies (AMEs) and to other countries and regions to promote cross-regional business activities through the FDI of multinational companies (Ambashi, 2017). Currently, ASEAN Economic Community (AEC) has implemented a new policy agenda in AEC Blueprint 2025 that has a goal to increase the attractiveness as a host for global investment through an open, transparent, and predictable investment regime in the region (The ASEAN Secretariat, 2019a). ASEAN countries have been reasonably successful in attracting FDI by showing an increase of FDI inflow in the third consecutive year since 2016. In 2018, FDI increased to \$155 billion, in spite of a declining trend in global FDI. (The ASEAN Secretariat, 2019b).

The impact of FDI on poverty eradication has been a long-standing debate from various empirical findings. There are three different points of view related to this study. The first view stated that poverty alleviation is driven by FDI and found a significantly positive relationship between these variables. Uttama (2015) provided evidence of FDI on poverty eradication using econometric models on panel data covered in six ASEAN countries from 1995 to 2011. The research found a positive and significant relationship between FDI inflows and poverty reduction in ASEAN countries. Thus, the main force of poverty alleviation in ASEAN countries is through FDI. A study by Ahmad et al. (2019) found a strongly significant relationship between the net inflow of FDI and poverty reduction in Asia. Additionally, the poverty reduction impact of FDI is greater in SAARC countries than in ASEAN countries, which concluded that FDI has a more significant impact on reducing poverty in less developed and poor countries of Asia. Moreover, Delis et al. (2015) researched on the impact of FDI, government investment, and labor on the level of poverty in Indonesia from 1993 until 2013. The results of this analysis showed that there is a negative and significant relationship between FDI and poverty.

Another research by Hung (2005) showed direct and indirect ways of FDI to reduce poverty in 12 provinces and cities of Vietnam from 1992 to 2002. The result claimed that inflows of FDI have a significant effect on poverty eradication through a labor-intensive industry. Shamim et al. (2014) and Zaman et al. (2012) studied the data of FDI on poverty in Pakistan. According to their studies, FDI showed a negative effect on Poverty, or an increase in FDI will decrease poverty. Likewise, a study conducted by Ucal (2014) found a statistically significant relationship between FDI and poverty eradication in selected 26 developing countries from 1990 until 2009. Employed data-set from North African countries for a period of 1990-2011, Soumaré (2015) research was certified a positive and strongly significant relationship between net FDI inflows and welfare improvement. This result also varies across regions. Bharadwaj (2014) investigated the relationship between FDI and poverty using panel data from selected 35 developing countries between 1990 and 2004. The study revealed that an inflow of capital through FDI has a beneficial effect to the poor. Another study by Fowowe \& Shuaibu (2014) explored the effect of FDI inflows on poverty from selected 30 African countries during 1981-2011. The results showed that FDI inflows along with good institutional quality and human capital development are associated with a reduction of poverty in African countries.

The second viewpoint stated that FDI creates a negative spillover impact to some countries and as a result an increase in poverty rates. A study by Huang et al. (2010) analyzed how inward and outward FDI affects poverty in 12 East Asia and Latin America middle-income countries between 1970 and 2005. Using unbalanced panel data, they found that outward and inward FDI is associated with more poverty. Moreover, by employed 
Autoregressive Distributed Lag (ARDL), Ali et al. (2009) research found that an increase in FDI inflows will increase poverty both long-run and short-run through direct and indirect ways in Pakistan during 1973-2008. Dhrifi et al. (2019) provided evidence of a relationship between FDI on poverty and CO2 using panel data of 98 developing countries including Asia, Africa, and Latin America region during 1995-2017. This study found that the relationship between FDI inflow and poverty is significantly negative in all regions except in Africa. They also stated that the reason behind this finding is due to the "crowding out" effect of the local firms, loss of domestic firms due to lower price offered by foreign companies, and higher wage provided by foreign companies therefore leaving the low-quality worker to the domestic firms.

The third standpoint stated that FDI does not have any influence on reducing poverty and show no significant impact of FDI on poverty eradication. Research by Gohou \& Soumare (2012) examined the effect of FDI on growth and poverty eradication across African countries in 1990-2007. They found a bi-directional causality link between FDI and log of GDP per capita. Thus, FDI reduces poverty and increases welfare. Additionally, they point out that the relationship between FDI and welfare are distinct over countries in Africa. Such as, in Central and Eastern Africa where the effect of FDI on poverty eradication is positive and significant, but the effect is not significant in Northern and Southern Africa. The relationship between FDI and poverty eradication was investigated by Ogunniyi \& Igberi (2014) in Nigeria over the period of 1980-2012. In this study, FDI has a positive but remains insignificant on real income per capita; hence, FDI has the probability of decreasing poverty in the country. Panel data of 13 Latin American countries is used by Quiñonez et al. (2018) to investigate the effect of FDI, macroeconomic stability, infrastructure, human capital development, and financial development in contributing to poverty eradication covered in the period of 2000-2014. They found out that inward FDI has an insignificant effect on poverty reduction while other variables showed a significant relationship with poverty alleviation.

The purpose of this study is to examine the impacts of foreign direct investment on poverty eradication in five ASEAN upper and lower middle-income countries throughout 1990-2018. Additionally, this research will also provide policy implications that the government can adopt to encourage poverty eradication in the selected five ASEAN countries. Therefore, the result of this study will give a broader insight into the advantage of FDI supported by a fine prevailing regulations and government control in reducing poverty instead of being resistant to an incoming FDI.

\section{METHODS}

Table 1. Research Variables

\begin{tabular}{cllc}
\hline No. & \multicolumn{1}{c}{ Variables } & \multicolumn{1}{c}{ Descriptions } & Code \\
\hline 1. & Poverty & Percentage of people living in poverty at less than \$3.20 a day & POV \\
2. & FDI & Net inflow of FDI as a ratio to GDP & FDI \\
3. & GDP & Logarithmic function of GDP per capita & LGDP \\
4. & Financial Development & Domestic credit provided by the financial sector as percentage to GDP & FD \\
5. & Education & Percentage of tertiary school enrollment & EDUC \\
\hline
\end{tabular}

Research variables shown in Table 1. This paper is conducted to analyze the impact of FDI on the percentage of people living in poverty at less than $\$ 3.20$ a day along with other predictor variables such as GDP per capita, domestic credit provided by the financial sector, and tertiary school enrolment rate. The subject of this research is limited to five upper and lower middle-income countries in ASEAN namely, Indonesia, Malaysia, Philippines, Vietnam, and Thailand. According to the World Bank as cited in (Tran, 2013) Malaysia is classified as an upper middle-income country; Indonesia, Philippines, Thailand sorted as lower middle-income countries; and Vietnam categorized as lower income countries. The classification is calculated using the World Bank Atlas that will signify each country as low-income economies with $\$ 1,045$ or less GNI per capita, lower-middle-income economies with $\$ 1,045-\$ 4,125$ GNI per capita, upper-middle-income economies with $\$ 4,125$ - \$12,736 GNI per capita, and high-income economies with $\$ 12,736$ or more GNI per capita (Fantom \& Serajuddin, 2016). Additionally, the selected 5 countries have grown rapidly at an average annual rate of $5.5 \%$ in terms of real GDP per capita and presumed as the Tiger Cub Economies because they are showing a considerable probability to compete with the four Asian Tigers such as Hong Kong, Singapore, Taiwan, and South Korea (Pham, 2012).

The type of dataset used in this research is unbalanced panel data which includes cross-section and time series data. The time series data period selected is from 1990 until 2018. Secondary-type data is used in this paper which was collected from World Development Indicators by the World Bank data library and PovcalNet by the World Bank. All the data used is open to the public. 
The research model refers to the model modified by Dhrifi et al. (2019). Thus, the model used is as follows:

$$
\mathrm{POV}_{\mathrm{it}}=\beta_{0}+\beta_{1} \mathrm{FDI}_{\mathrm{it}}+\beta_{2} \mathrm{LGDP}_{\mathrm{it}}+\beta_{3} \mathrm{FD}_{\mathrm{it}}+\beta_{4} \mathrm{EDUC}_{\mathrm{it}}+\mu_{\mathrm{it}}
$$

Where,

$\mathrm{POV}_{\text {it }}=$ Poverty headcount ratio at $\$ 3.20$ a day (i) at time (t)

$\beta_{0} \quad=$ Intercept

$\mathrm{FDI}_{\mathrm{it}}=$ The ratio of foreign direct investment inflow to GDP (i) at time (t)

LGDP $_{i t}=$ Gross Domestic Product per capita of country in 2010 constant U.S dollar (i) at time (t)

$\mathrm{FD}_{\mathrm{it}} \quad=$ The ratio of domestic credit provided by financial sector to GDP (i)

$\mathrm{EDUC}_{\mathrm{it}}=$ The gross ratio of tertiary school enrollment (i) at time (t)

$\mu_{\mathrm{it}} \quad=$ Error term

Table 2. Descriptive Statistics

\begin{tabular}{|c|c|c|c|c|c|c|}
\hline Variable & & Mean & Std. Dev. & Min & Max & Observations \\
\hline \multirow[t]{3}{*}{ POV } & overall & 33.85731 & 27.98542 & .1 & 90.2 & $N=145$ \\
\hline & between & & 24.92648 & 5.158793 & 62.92828 & $\mathrm{n}=5$ \\
\hline & within & & 16.81275 & -9.040621 & 68.95938 & $\mathrm{~T}=29$ \\
\hline \multirow[t]{3}{*}{ FDI } & overall & 3.143588 & 2.356535 & -2.75744 & 11.93948 & $N=145$ \\
\hline & between & & 1.930876 & 1.20184 & 5.954562 & $\mathrm{n}=5$ \\
\hline & within & & 1.596847 & -.9342718 & 9.128509 & $\mathrm{~T}=29$ \\
\hline \multirow[t]{3}{*}{ LGDP } & overall & 7.909739 & .7761249 & 6.071393 & 9.402619 & $\mathrm{~N}=145$ \\
\hline & between & & .7960726 & 6.848367 & 8.953352 & $\mathrm{n}=5$ \\
\hline & within & & .3030904 & 7.132765 & 8.644352 & $\mathrm{~T}=29$ \\
\hline \multirow[t]{3}{*}{ FD } & overall & 85.07293 & 42.29918 & 15.71207 & 178.4178 & $\mathrm{~N}=142$ \\
\hline & between & & 38.46473 & 47.14849 & 128.7928 & $\mathrm{n}=5$ \\
\hline & within & & 23.97163 & 26.93569 & 153.0744 & T-bar $=28.4$ \\
\hline \multirow[t]{3}{*}{ EDUC } & overall & 25.44103 & 12.76617 & 1.53302 & 52.2557 & $\mathrm{~N}=140$ \\
\hline & between & & 8.98065 & 13.84002 & 36.96221 & $\mathrm{n}=5$ \\
\hline & within & & 9.981709 & 4.338531 & 44.76464 & $\mathrm{~T}=28$ \\
\hline
\end{tabular}

Source: Author Calculation

From the descriptive statistics of dependent and independent variables for panel data of 5 ASEAN countries (Table 2), the poverty headcount mean is 33,86 percent with interpolated 145 observations. Foreign Direct Investment inflow (FDI) mean is 3,14 percent and 145 observations. The log gross domestic product per capita has a mean of 7.91 percent and the number of observations is 145 . Domestic credit provided by the financial sector (FD) mean is 85,07 percent to GDP ratio for 142 observations. For this variable, there are three missing data at the beginning of the period; thus, performing interpolation will not be implemented. Meanwhile, tertiary school enrollment (EDUC) mean is 25,44 percent of 140 observations. Variable EDUC also found missing data either in the beginning, middle, or the last period. Hence, interpolation will only load the data in the middle of the period and leave the data at the beginning and last period blank.

\section{RESULTS}

This research uses the Feasible Generalized Least Square (FGLS) method to analyze panel data of five ASEAN countries from 1990 until 2018. According to Blackwell III (2005), Feasible Generalized Least Square (FGLS) can be chosen with the presence of heteroskedasticity, panel autocorrelation, and contemporaneous correlation (HPAC) in fixed effects. Additionally, to use FGLS, the time period must be larger than the panels (Wiggins, 2001). In this case, the time period (28 years) is larger than the panels (5 countries). 
Table 3. Chow Test

\begin{tabular}{ccc}
\hline Group & Prob $>$ F & $\alpha$ \\
\hline ASEAN (5 Countries) & 0.0000 & 0.05 \\
\hline
\end{tabular}

Source: Author Calculation

At first, chow test is necessary to determine which method to use for panel data. This test is carried out to examine the better method between fixed-effect or pooled least square. From the calculation (Table 3), the p-value (Prob $>F)$ is smaller than Alpha $(\alpha=5 \%)$ thus, $\mathrm{H} \_0$ is rejected. Using a fixed effect method is better than pooled least square. The next step is to perform the Hausman test.

Table 4. Hausman Test

\begin{tabular}{ccc}
\hline Group & Prob $>$ chi2 & $\alpha$ \\
\hline ASEAN (5 Countries) & 0.0317 & 0.05 \\
\hline
\end{tabular}

Source: Author Calculation

The Hausman test is conducted to determine a better method between the random effect model and the fixed effect model. Based on the result (Table 4), Prob $>$ chi2 is lower than $\alpha$ which is 0,05 . Thus, H_0 is rejected and using fixed effect method is better than the random effect.

Table 5. Coefficient Correlation Matrix

\begin{tabular}{ccccc}
\hline & FDI & LGDP & FD & EDUC \\
\hline FDI & 1.0000 & & & \\
LGDP & -0.1252 & 1.0000 & 1.0000 & 1.0000 \\
FD & 0.2123 & 0.6851 & 0.4158 & 0.5725 \\
EDUC & -0.2101 & & & \\
\hline
\end{tabular}

Source: Author Calculation

Classical assumption tests are conducted to determine the suitable estimator and the reliability of the empirical model. The first test to be conducted is a multicollinearity test. One of the tests regarding the multicollinearity problem is using a correlation coefficient matrix (Table 5). This test shows correlation coefficient table between variables with each cell indicating the correlation between two variables. Although the presence of multicollinearity problems between independent variables may not violate the regression assumptions and still correctly estimate the standard errors, it will create a problem in estimating the coefficient with small standard error (Gujarati \& Porter, 2009).

Table 6. Autocorrelation Test

\begin{tabular}{ccc}
\hline Group & Prob $>$ F & $\alpha$ \\
\hline ASEAN (5 Countries) & 0.0120 & 0.05 \\
\hline Source: Author Calculation & &
\end{tabular}

Table 7. Heteroskedasticity Test

\begin{tabular}{ccc}
\hline Group & Prob $>$ F & $\alpha$ \\
\hline ASEAN (5 Countries) & 0.0000 & 0.05 \\
\hline
\end{tabular}

Source: Author Calculation

Next, the Breusch-Pagan test is conducted to identify heteroskedasticity problems in the model (Table 6). The last test is to detect the spatial autocorrelation in residuals (Table 7). Under the presence of heteroskedasticity and autocorrelation, the estimators are still linear and unbiased, but it could cause a biased variance of the estimated parameters and misleading t, F, and $\chi 2$, therefore resulting in misleading conclusions (Gujarati \& Porter, 2009).

In this model, there is no multicollinearity problem between independent variables, but there is autocorrelation as well as heteroskedasticity problem. However, the problems of heteroscedasticity and autocorrelation can be fixed using Feasible Generalized Least Square (FGLS) method according to Blackwell III (2005). In consequence, the problem in the research model has been solved.

The equation results of the estimation model can be expressed as (Table 8):

$$
\mathrm{POV}_{\mathrm{it}}=168.7-2.963 \mathrm{FDI}_{\mathrm{it}}-10.12 \mathrm{LGDP}_{\mathrm{it}}-0.250 \mathrm{FD}_{\mathrm{it}}-0.948 \mathrm{EDUC}_{\mathrm{it}}
$$


Table 8. Regression result

\begin{tabular}{|c|c|}
\hline \multicolumn{2}{|c|}{ Dependent Variable: Poverty Headcount Ratio } \\
\hline Variables & Feasible Generalized Least Square Regression \\
\hline \multirow[t]{2}{*}{ FDI } & $-2.963 * * *$ \\
\hline & $(0.426)$ \\
\hline \multirow[t]{2}{*}{ LGDP } & $-10.12 * * *$ \\
\hline & $(1.814)$ \\
\hline \multirow[t]{2}{*}{ FD } & $-0.250 * * *$ \\
\hline & $(0.0307)$ \\
\hline \multirow[t]{2}{*}{ EDUC } & $-0.948 * * *$ \\
\hline & $(0.0856)$ \\
\hline \multirow[t]{2}{*}{ Constant } & $168.7 * * *$ \\
\hline & $(12.60)$ \\
\hline Observations & 137 \\
\hline Number of NATIONS & 5 \\
\hline \multicolumn{2}{|c|}{ Standard errors in parentheses } \\
\hline \multicolumn{2}{|c|}{$* * * \mathrm{p}<0.01, * * \mathrm{p}<0.05, * \mathrm{p}<0.1$} \\
\hline
\end{tabular}

\section{DISCUSSIONS}

This section will discuss the research result from the previous section. The analysis for the results will be focused on the impact of each independent variable on the dependent variable and comparing the estimation results with the hypothesis mentioned before and existing economic theory. According to the estimation results, when other variables are being fixed at a constant point, the ratio of people living under the poverty line at $\$ 3.20$ a day in five ASEAN countries during 1990-2018 is 168.7.

As specified by the estimation result, the Effect of FDI on poverty is negative, shown by the negative coefficient sign of FDI. In addition, this variable is significant on poverty eradication at the one percent level. This result also suggests that an increase by one percent in FDI inflow will decrease poverty rates on average of 2.963 percent. This result is in accordance with the research done by Uttama (2015) that stated inflows of FDI are found to be positively significant with the eradication of poverty. This signifies that FDI liberalization and integration in economics significantly affect poverty eradication in ASEAN countries. Similarly, Hung (2005) research found that the relationship between poverty eradication and FDI inflow is significantly positive. Therefore, it is aligned with the assumption of the direct and indirect effects of FDI on poverty reduction. Moreover, consistent with the result, Fowowe \& Shuaibu (2014) stated that FDI is statistically significant and negatively related to poverty headcount, besides the impact of FDI on poverty reduction will be relatively higher in poorer countries, have a more developed financial systems, and higher quality of human capital. This result is also aligned with the research done by Shamim et al. (2014), where FDI and poverty eradication have a significantly positive relationship. They also signify that the effectiveness of FDI in poverty eradication is due to its positive influence on economic growth, human capital development, recessive institutions, and "crowding in" of domestic investment.

Based on the estimation result, the log of GDP per capita (LGDP) variable has a coefficient value of -10.12 and a probability less than 0.05 . This means that a log of GDP per capita has a negative and significant impact on the poverty rate. In conclusion, every increase of one percent in LGDP may decrease of the poverty rate on average by 0.10 percent. This result is consistent with Dhrifi et al. (2019) that found a positive association between GDP per capita and poverty eradication. Furthermore, they stated that this variable acts as the leading effect on reducing poverty. Besides, Ijaiya et al. (2011) affirms that a positive change in economic growth does promotes poverty alleviation as shown by an increase in household consumption-expenditure. The negative relationship between economic growth and poverty is also supported by Agrawal (2007), which indicates that countries whose experience a higher growth rate in GDP also experience a higher government revenue. Therefore, resulting in a large decline of poverty engender from higher employment, wage, and outlay in the social sector.

Another important aspect to be highlighted is that the domestic credit provided by the financial sector as a proxy of financial development (FD) variable is statistically significant at one percent. The coefficient sign of 
this variable is linear with the expectation which is negative. To interpret the result, as an increase in financial development by one percent may result in a decrease of poverty rate on average by 0.250 percent. The result corresponds with studies done by Dhrifi et al. (2019) that financial development is a vital instrument which may also be used as a tool of poverty alleviation. Shamim et al. (2014) also supported this result, which specified that financial development has a negative and statistically significant impact on poverty reduction in the long run due to lower charges to additional loans, increase in the velocity of more money in the economy, and a higher savings. Supporting this view Jeanneney \& Kpodar (2011) stated that people living under poverty are subject to scarce liquid assets to invest in physical and human capital. Therefore, by giving them access to liquid assets through financial intermediaries will be beneficial for them to generate a higher return, increase savings, maintain their consumption, and decrease their vulnerability.

Tertiary school enrollment as a proxy of education (EDUC) variable has a negative and statistically significant effect on poverty rate. The coefficient for this variable is -0.948 . The interpretation for this variable is that an increase by one percent in tertiary school enrollment would result in a decrease of poverty rate on average by 0.948. This result is aligned with research done by Awan et al. (2011) and Dhrifi et al. (2019) that found experience and educational achievement have a negative effect upon poverty. Additionally, education is considered to be the primary weapon against poverty as there is a higher chance that a person will not be poor if they have a higher level of education. Further support is shown in Gounder \& Xing (2012) research that stated higher educational level would reduce the possibility of living in poverty due to a higher chance of getting a formal employment. Moreover, Zamurrad Janjua \& Ahmed Kamal (2011) stated that education can still play a role as a poverty alleviation factor even in a country with low growth of income per capita and small change in income inequality.

\section{CONCLUSIONS}

The main purpose of this research is to examine the impact of FDI on poverty eradication in 5 ASEAN upper and lower middle-income countries using panel data covered from 1990 to 2018. This research employs a Feasible Generalized Least Square (FGLS) method and assumes the variation across entities is fixed and separated among the control or the independent variables in the model. Based on the result revealed, the foreign direct investment (FDI) is significant at one percent level and has a negative effect on poverty headcount ratio. Thus, this result signifies that an increase in FDI inflows is associated with a decrease in poverty. Additionally, this research has conducted other three determinants of poverty eradication such as, GDP per capita, domestic credit provided by the financial sector, and education. All of these variables are significant at one percent and have a negative impact on the poverty headcount ratio.

Based on the findings of this research, there are several policy implications that the government can adopt to encourage poverty reduction. Firstly, the policies implemented by the government should be creating attractive economic and political conditions by continuing structural economic reform policies, especially in terms of bureaucratic efficiency and business licensing to promote and encourage FDI. Additionally, the government can also attract investors by providing tax incentives. Secondly, due to the characteristics of developing countries with high labor supply, policies that promote labor-intensive industries FDI should be implemented. This type of FDI creates more job opportunities and income generation that will directly impact the poverty reduction caused by unemployment. The policies should also include training courses or increasing educational attainment for the people and setting the appropriate minimum wage level that will help people recover from poverty.

Policy to support a higher level of education is needed because it will lower the number of poor people by imparting knowledge and skills that will increase the opportunity of getting formal employment and higher wages. Therefore, as education increases wages, people will be able to comply with their primary necessities, raising their living standards, then causing the number of people living under poverty to fall. However, suppose the wages paid by the investors are below the poverty line. In that case, the impact of the investment will not contribute to reducing poverty and will only push people down to the poverty line. Thus, the investors have to pay their employees above the poverty line to increase the impact of the investment in reducing poverty.

Thirdly, revenue received from FDI tax revenue, rent fees, export, and import operations should facilitate further economic activities, safety nets for the poor, and infrastructure investment. The contributions of foreign corporations in social security could help the government minimize the cost of creating safety nets and developing other social welfare programs. Lastly, policies regarding financial development which improve savings mobilization should be implemented in order to reduce poverty. Following those policies, the government also needs to maintain financial stability by controlling the money supply, inflation, safeguarding the economy from external shocks, implementing an adequate legal system, and strict banking supervision. 


\section{REFERENCES}

Agrawal, P. 2007. Economic Growth and Poverty Reduction: Evidence from Kazakhstan. Asian Development Review, 24(2), 90-115.

Ahmad, F., Draz, M. U., Su, L., Ozturk, I., Rauf, A., \& Ali, S. 2019. Impact of FDI Inflows on Poverty Reduction in the ASEAN and SAARC Economies. Sustainability (Switzerland), 11(9), 1-24. https://doi.org/10.3390/ su11092565

Ali, M., Nishat, M., \& Anwar, T. 2009. Do Foreign Inflows Benefit Pakistani Poor? Pakistan Development Review, 48(4), 715-738. https://doi.org/10.30541/v48i4iipp.715-738

Ambashi, M. 2017. ASEAN as an FDI attractor: How Do Multinationals Look at ASEAN? Economic Research Institute for ASEAN and East Asia., Policy Brief 2016-04. http://hdl.handle.net/11540/6758

Awan, M., Malik, N., Sarwar, H., \& Waqas, M. 2011. Impact of Education on Poverty Reduction. International Journal of Academic Research, 3(1), 659-664. https://mpra.ub.uni-muenchen.de/id/eprint/31826

Bharadwaj, A. 2014. Reviving the Globalization and Poverty Debate: Effects of Real and Financial Integration on the Developing World. Advances in Economics and Business, 2(1), 42-57. https://doi.org/10.13189/ aeb.2014.020107

Blackwell III, J. L. 2005. Estimation and Testing of Fixed-effect Panel-data Systems. The Stata Journal, 5(2), 202-207.

Delis, A., Mustika, C., \& Umiyati, E. 2015. Pengaruh FDI Terhadap Kemiskinan Dan Pengangguran Di Indonesia 1993-2013. Jurnal Paradigma Ekonomika, 10(01), 231-245.

Dhrifi, A., Jaziri, R., \& Alnahdi, S. 2019. Does Foreign Direct Investment and Environmental Degradation Matter for Poverty? Evidence from Developing Countries. Structural Change and Economic Dynamics, 52, 13-21. https://doi.org/https://doi.org/10.1016/j.strueco.2019.09.008

Fantom, N. \&, \& Serajuddin, U. 2016. The World Bank's Classification of Countries by Income. World Bank Policy Research Working Paper 7528, January, 1-3. https://doi.org/10.1596/1813-9450-7528

Fowowe, B., \& Shuaibu, M. I. 2014. Is Foreign Direct Investment Good for the Poor? New Evidence from African Countries. Economic Change and Restructuring, 47(4), 321-339. https://doi.org/10.1007/s10644014-9152-4

Gohou, G., \& Soumaré, I. 2012. Does Foreign Direct Investment Reduce Poverty in Africa and are There Regional Differences? World Development, 40(1), 75-95. https://doi.org/10.1016/j.worlddev.2011.05.014

Gounder, R., \& Xing, Z. 2012. Impact of Education and Health on Poverty Reduction: Monetary and Non-monetary Evidence from Fiji. Economic Modelling, 29(3), 787-794. https://doi.org/10.1016/j.econmod.2012.01.018

Gujarati, D. N., \& Porter, D. C. 2009. Basic Econometrics (Fifth). McGraw-Hill.

Hanusch, M., Nguyen, H., \& Algu, Y. 2018. Exchange Rate Volatility and FDI Inflows: Evidence from CrossCountry Panel Data. World Bank MTI Global Practice Discussion Paper No.2. https://doi.org/10.1596/29911

Huang, C. H., Teng, K. F., \& Tsai, P. L. 2010. Inward and Outward Foreign Direct Investment and Poverty: East Asia vs. Latin America. Review of World Economics, 146(4), 763-779. https://doi.org/10.1007/s10290010-0069-3

Hung, T. 2005. Impacts of Foreign Direct Investment on Poverty Reduction in Vietnam. Discussed Paper, GRIPS, Vietnam, 1-24. http://gwww.grips.ac.jp/vietnam/VDFTokyo/Doc/18TTHungPaper.pdf

Iamsiraroj, S. 2016. The Foreign Direct Investment-economic Growth Nexus. International Review of Economics and Finance, 42, 116-133. https://doi.org/10.1016/j.iref.2015.10.044

Ijaiya, G. T., Ijaiya, M. A., Bello, R. A., \& Ajayi, M. A. 2011. Economic Growth and Poverty Reduction in Nigeria. International Journal of Business and Social Science, 2(15), 147-154.

Jeanneney, S. G., \& Kpodar, K. 2011. Financial Development and Poverty Reduction: Can There Be a Benefit without a Cost? Journal of Development Studies, 47(1), 143-163. https://doi.org/10.1080/00220388.201 0.506918

Jugurnath, B., Chuckun, N., \& Fauzel, S. 2016. Foreign Direct Investment \& Economic Growth in Sub-Saharan Africa: An Empirical Study. Theoretical Economics Letters, 06(04), 798-807. https://doi.org/10.4236/ tel.2016.64084

Klein, M., Aaron, C., \& Hadjimichael, B. 2001. Foreign Direct Investment and Poverty Reduction. World Bank Policy Research Working Paper 2613. https://doi.org/https://doi.org/10.1596/1813-9450-2613

Lee, J. W. 2013. The Contribution of Foreign Direct Investment to Clean Energy Use, Carbon Emissions and Economic Growth. Energy Policy, 55, 483-489.

Nizar, C., Hamzah, A., \& Syahnur, S. 2013. Pengaruh Investasi dan Tenaga Kerja terhadap Pertumbuhan Ekonomi serta Hubungannya terhadap Tingkat Kemiskinan di Indonesia. Jurnal Ilmu Ekonomi Pascasarjana Universitas Syiah Kuala, 1(2), 1-8. 
Ogunniyi, M. B., \& Igberi, C. O. 2014. The Impact of Foreign Direct Investment [FDI] on Poverty Reduction in Nigeria. Journal of Economics and Sustainable Development, 5(14), 73-83. https://doi.org/10.15304/ rge.27.2.5664

Pham, T. 2012. The Relationship Between Openness and Economic Performance a Case Study of the Five Leading Emerging Markets in Southeast Asia: Vietnam Philippines Thailand Indonesia Malaysia. https:// digitalworks.union.edu/theses/879

Prince, W., \& Fantom, N. 2014. World Development Indicators 2014. The World Bank, 1(87946), 1-137. https:// doi.org/10.1017/CBO9781107415324.004

Quiñonez, P., Sáenz, J., \& Solórzano, J. 2018. Does Foreign Direct Investment Reduce Poverty? The Case of Latin America in the Twenty-first Century. Business and Economic Horizons, 14(3), 488-500. https://doi. org/10.15208/beh.2018.35

Shamim, A., Azeem, P., \& Naqvi, S. M. M. A. 2014. Impact of Foreign Direct Investment on Poverty Reduction in Pakistan. International Journal of Academic Research in Business and Social Sciences, 4(10), 465-490. https://doi.org/10.6007/ijarbss/v4-i10/1244

Smith, S. C., \& Todaro, M. . 2015. Economic Development (Twelfth). Pearson.

Soumaré, I. 2015. Does FDI Improve Economic Development in North African Countries? Applied Economics, 47(51), 5510-5533. https://doi.org/10.1080/00036846.2015.1051655

The ASEAN Secretariat. 2019a. ASEAN Integration Report 2019. The ASEAN Secretariat Library Catalogue in Publication Data. https://asean.org/storage/2019/11/ASEAN-integration-report-2019.pdf

The ASEAN Secretariat. 2019b. ASEAN Investment Report 2019 FDI in Services: Focus on Health Care. The ASEAN Secretariat Library Catalogue in Publication Data. https://doi.org/10.1007/s13398-014-0173-7.2

Tran, V. T. 2013. The Middle-income Trap: Issues for Members of the Association of Southeast Asian nations. In ADBI Working Paper 421. https://doi.org/10.2139/ssrn.2266239

Ucal, M. Ş. 2014. Panel Data Analysis of Foreign Direct Investment and Poverty from the Perspective of Developing Countries. Procedia - Social and Behavioral Sciences, 109, 1101-1105. https://doi.org/10.1016/j. sbspro.2013.12.594

UNCTAD. 2018. World Investment Report 2018: Investment and New Industrial Policies. In United Nations Publication. https://doi.org/https://doi.org/10.18356/ebb78749-en.

Uttama, N. P. 2015. Foreign Direct Investment and the Poverty Reduction Nexus in Southeast Asia. Poverty Reduction Policies and Practices in Developing Asia, 281-298. https://doi.org/10.1007/978-981-287-420-7

Wiggins, V. 2001. How Does xtgls Differ from Regression Clustered with Robust Standard Errors? https://www. stata.com/support/faqs/statistics/xtgls-versus-regress/

Zaman, K., Khan, M. M., \& Ahmad, M. 2012. The Relationship Between Foreign Direct Investment and ProPoor Growth Policies in Pakistan: The New Interface. Economic Modelling, 29(4), 1220-1227. https://doi. org/10.1016/j.econmod.2012.04.020

Zamurrad Janjua, P., \& Ahmed Kamal, U. 2011. The Role of Education and Income in Poverty Alleviation: A Cross-country Analysis. The Lahore Journal of Economics, 16(1), 143-172. https://doi.org/10.35536/ 1je.2011.v16.i1.a6 